\title{
Protein structure groups seek to draft common ground rules
}

Washington

Scientists from Britain, the United States, France, Germany, Israel and Japan are taking preliminary steps towards establishing common procedural guidelines for research in structural genomics. The move could lay the groundwork for a single international structural-genomics effort comparable to the Human Genome Project (HGP).

A meeting to be held in April at the Sanger Centre outside Cambridge, England, will discuss ground rules for collaboration, such as common policies on data release and intellectual property — issues at the heart of collaboration on raw sequencing under the HGP.

The goal of structural genomics is to catalogue the folding properties of all natural proteins. Genes with sequence similarities encode protein structures that resemble one another, and these can be used to group protein shapes into families, reducing the time and expense needed to obtain their structure.

Assembling and analysing an entire set of proteins poses greater technical challenges than sequencing (see Nature 402, 703; 1999), but dividing up responsibility among laboratories could cut the project down to a manageable size in each participating country.

The genome project is a "possible model of collaboration" for an international structural-genomics effort, says Michael Morgan, chief executive of the Wellcome Trust's genome campus.

Barbara Skene, a scientific programme manager at the Wellcome Trust, hopes the meeting will at least result in a database telling scientists which proteins other laboratories are working on, and how far they have got. This could prevent duplication of effort, she says, and help to communicate how different groups solve common problems.

Participants in an international effort will need to agree on standards for the quality of data released into a central database, as well as a time frame - issues heatedly debated during the early stages of the human genome programme. But additional agreement on scientific matters - such as which are the most representative proteins in a family, and how best to divide them between research groups - also need to be considered.

Furthermore, sequencing the genome of a particular organism is highly automated and has a definite end-point, whereas structural genomics is more time-consuming, has a less clear finishing line, and has more potential technical bottlenecks, such as the purification phase, says Skene. Such limitations may even affect the starting point, she adds. For example, membrane proteins, which make up an estimated 25 per cent of known pro-

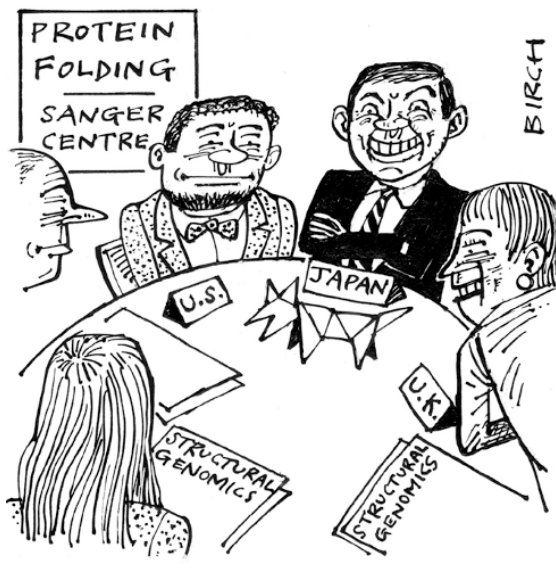

teins, cannot easily be crystallized, so their structure cannot be determined.

Identifying and addressing procedural similarities between sequencing and structural genomics seems like a good starting point for collaboration, says Marvin Cassman, director of the US National Institute of General Medical Sciences (NIGMS).

NIGMS will launch its own structuralgenomics initiative next autumn (see Nature 400, 494; 1999). Cassman hopes that the April meeting, which is co-sponsored by NIGMS, will help set international guidelines for data release and sharing of materials.

Cassman admits that reaching consensus on scientific issues, which are not on the agenda for the April meeting, will be tougher. After an initial five-year pilot stage, the NIGMS programme aims to generate 10,000 structures from as many protein families as possible. But some groups intend to characterize every protein structure within small organisms such as the bacterium Mycoplasma genitalium, while others may try to obtain as many structures as possible involved in a single cellular process, such as cell division.

These differing approaches could lead to duplication of effort both nationally and internationally. "Some overlap will be good" because it will allow for quality control, says Stephen Burley, a professor at Rockefeller University and investigator with the Howard Hughes Medical Institute. But too much duplication would be wasteful, he adds.

Helen Berman, however, director of the Protein Data Bank at Rutgers University, says organizing an international effort for protein structures "probably won't be any more or less difficult" than for sequencing efforts.

The need for greater coordination is being watched by the newly renamed Global Science Forum of the Paris-based Organization for Economic Cooperation and Development (OECD).

Paul Smaglik
Austrian body pleads for normal contacts despite EU freeze

Munich

The Austrian Science Fund (FWF), the country's main research-funding agency, has called on the international scientific community not to turn its back on the country in reaction to the inclusion of the right-wing Freiheitliche Partei Österreichs (FPÖ) in its new coalition government.

The move follows a decision by the European Union to ask its member states to freeze bilateral contacts with Austria. French research minister Claude Allègre said in a television interview last Sunday that all scientific projects between France and Austria were being "frozen".

"The situation is very worrying," wrote Arnold Schmidt, president of the FWF, in an open letter to scientists across Europe. "I appeal to all scientists to maintain or increase contact and cooperation with scientists working in Austria."

The FWF is particularly concerned that researchers will choose to stay away from scientific conferences held in Austria. "If you stay away you will hit science, but not the FPÖ," he says.

Some scientific societies, such as the European Group of Blood and Marrow Transplantation, are already considering whether to relocate meetings planned for Austria. The Edinburgh International Conference Centre, for example, claims to have been approached by "a number of Austrian organizers" who are considering relocating their events.

Meinhard Regler, vice-president of the Institute for High Energy Physics in Vienna, who is organizing the biannual European Particle Accelerator Conference, says the number of US registrants for this year's meeting in Vienna is likely to be much lower than usual, although this may be partly due to domestic budget restrictions.

Many Austrian scientists are keen to distance themselves from the FPÖ and its political ideology. "We are totally opposed to the nationalist and xenophobic sentiments expressed by some FPÖ politicians," said Peter Michor and Klaus Schmidt, scientific directors of the Vienna-based Erwin Schrödinger Institute for Theoretical Physics.

But Kim Nasmyth, the director of the Institute for Molecular Pathology in Vienna - which hosts young researchers from 23 countries - is optimistic that "colleagues everywhere... will not put us in the same boat as some politicians". Quirin Schiermeier and Patrick Weydt 